\title{
Выращивание и оптические свойства сцинтилляционных кристаллов BaBrI:Sm²+
}

\author{
А.А. Шалаев ${ }^{1,2}$, А.И. Русаков ${ }^{1}$, Р.Ю. Шендрик ${ }^{1}$ \\ ${ }^{1}$ Институт геохимии им. А.П. Виноградова СО РАН, Иркутск, 664033, Фаворского 1-А \\ ${ }^{2}$ Иркутский государственный университет, Иркутск, 664025, бул. Гагарина, 20 \\ тел: +7 (3952) 51-14-62, эл.nочта: alshal@igc.irk.ru
}

DOI 10.34077/RCSP2021-118

Кристаллы щелочноземельных галогенидов, активированные редкоземельными ионами, являются перспективными сцинтилляционными материалами. Для них характерна относительно небольшая ширина запрещённой зоны (4-6 eV), что способствует эффективному образованию электроннодырочных пар на каждый поглощённый фотон ионизирующего излучения. В следствии этого, системы с различными комбинациями щелочноземельных иодидов в качестве решёткообразующих элементов имеют высокие значения световыхода и хорошее энергетическое разрешение [1].

На сегодняшний день практически все коммерческие сцинтилляторы разработаны для регистрации люминесценции фотоэлектронными умножителями (ФЭУ) с максимумом чувствительности в диапазоне 400-440 нм. Для регистрации люминесценции кристаллов, активированных самарием, необходимы фотоприёмники, работающие в видимой и инфракрасной области. Это могут быть полупроводниковые лавинные фотодиоды, с максимумом чувствительности в области 600-800 нм и имеющие намного большую квантовую эффективность (80-90\%), чем традиционные ФЭУ (до 35 \%) [2]. Их использование в итоге будет способствовать разработке нового класса эффективных сцинтилляционных материалов с длинноволновым излучением в красном или ближнем инфракрасном диапазоне.

В работе обсуждаются особенности выращивания методом Бриджмена кристаллов BaBrI, активированных ионами $\mathrm{Sm}^{2+}$. Методам ИСП-МС была оценена фактическая концентрация самария, вошедшего в выращенные кристаллы. Полученные результаты показали более низкий уровень содержания самария в кристаллах по сравнению с вводимыми в шихту концентрациями активатора. Несмотря на этот факт в выращенных кристаллах наблюдается высокий световой выход люминесценции и прослеживается явная корреляция между вводимой в шихту концентрацией самария и интенсивностью люминесценции. Установлено, что самарий входит в кристалл в двухвалентном состоянии. При фото- и рентгеновском возбуждении кристаллов наблюдается сильная люминесценция в области 740 нм со световыходом, сопоставимым световыходу такого традиционного сцинтиллятора, как CsI-Tl. Учитывая то, что регистрацию свечения в красной области таких кристаллов возможно осуществлять с помощью полупроводниковых лавинных светодиодов с большей по сравнению с традиционными ФЭУ квантовой эффективностью, можно ожидать, что кристаллы BaBrI, активированные ионами $\mathrm{Sm}^{2+}$ могут стать перспективной матрицей для создания высокоэффективных сцинтилляционных детекторов нового класса.

\section{Лuтература}

[1] M. Nikl и др. // Advanced Optical Materials 20153 (4), 463

[2] W. Wolszczak и др. // Phys. Status Solidi RRL 2019. 900158, 1. 